\title{
Role of FSH in regulating granulosa cell division and follicular atresia in rats
}

\author{
J. J. Peluso* and R. W. Steger $\dagger$ \\ Reproductive Physiology Laboratories, C. S. Mott Center for Human Growth and Development, \\ Wayne State University School of Medicine, Detroit, Michigan 48201, U.S.A.
}

\begin{abstract}
Summary. The effects of PMSG on the mitotic activity of granulosa cells and atresia of large follicles in 24-day-old rats were examined. The results showed that the labelling index (1) decreased in atretic follicles parallel with a loss of FSH binding, and (2) increased in hypophysectomized rats treated with FSH. It is concluded that FSH stimulates granulosa cell divisions and that atresia may be caused by reduced binding of FSH to the granulosa cells.
\end{abstract}

\section{Introduction}

Granulosa cells of primary follicles undergo repeated cell divisions and thus result in the growth of the follicle (Pederson, 1972). These divisions are stimulated by FSH and oestrogen, but FSH is also necessary for antrum formation (Goldenberg, Vaitukaitus \& Ross, 1972). The stimulatory effects of FSH on granulosa cell divisions may be mediated through an accelerated oestrogen synthesis because FSH induces aromatizing enzymes and enhances oestrogen synthesis within the granulosa cells (Dorrington, Moon \& Armstrong, 1975; Armstrong \& Papkoff, 1976).

Although many follicles advance beyond the primordial stage, most undergo atresia (Weir \& Rowlands, 1977). Atretic follicles are characterized by a low mitotic activity, pycnotic nuclei, and acid phosphatase activity within the granulosa cell layer (Greenwald, 1974). The atresia of antral follicles occurs in three consecutive stages (Byskov, 1974). In Stage I, there is a slight reduction in the frequency of granulosa cell divisions and pycnotic nuclei appear. Follicles in Stage II show a further reduction in the number of granulosa cell divisions and pycnotic nuclei and leucocytes are observed in the antrum. In Stage III, the granulosa cells have stopped dividing and the antral cavity begins to collapse. Since granulosa cell divisions are regulated by FSH and since the effects of FSH are mediated through receptors located within the granulosa cells (Midgley, 1972), a series of experiments were conducted to examine the changes in FSH binding sites during follicular atresia and to correlate these changes with the frequency of granulosa cell divisions.

\section{Materials and Methods}

\section{Experiment I}

Twenty-three (23) female Wistar rats, 24 days of age, were housed in a controlled environment $\left(24^{\circ} \mathrm{C}, 45 \%\right.$ humidity and $14 \mathrm{~h}$ light $/ 24 \mathrm{~h}$ ). Nineteen (19) of these rats received 5 i.u. PMSG (Ayerst AY-24,293-X-6) i.p. at 09:00 h on Day 24. The 4 remaining rats were not treated. The untreated rats were killed by decapitation at 09:00 h on Day 26, and groups of 4-5 PMSG-treated rats were killed at $48,56,72$ and $96 \mathrm{~h}$ after treatment. The ovaries were removed and one ovary from each rat was fixed in Bouin's fluid or placed in an embedding medium (OCT compound: Ames Co., Elkhart, Indiana), frozen in a solid $\mathrm{CO}_{2}$-ethanol bath and stored at $-20^{\circ} \mathrm{C}$. Bouin-fixed ovaries were embedded in paraffin wax, sectioned and stained with haematoxylin and eosin.

* Present address: Department of Biology, Loyola University of Chicago, Chicago, Illinois 60626, U.S.A.

$\dagger$ Present address: Department of Physiology, Michigan State University, East Lansing, Michigan 48824, U.S.A. 
FSH binding sites were localized as described by Peluso, Steger \& Hafez (1976). Frozen sections were cut in a cryostat at $15 \mu \mathrm{m}$, then incubated for $1 \mathrm{~h}$ at $37^{\circ} \mathrm{C}$ with ${ }^{125}$ I-labelled human FSH $\left(4.2 \times 10^{5}\right.$ c.p.m. $/ 25 \mu \mathrm{l})$. The human FSH was purchased from Calbiochem (LaJolla, California, U.S.A.) and iodinated with ${ }^{125} \mathrm{I}$ by the chloramine-T method of Greenwood, Hunter \& Glover (1963). The specific activity of ${ }^{125} \mathrm{I}$-hFSH was $50 \mu \mathrm{Ci} / \mu \mathrm{g}$ protein. After incubation with ${ }^{125}$ I-labelled $\mathrm{hFSH}$, the sections were washed, air dried and dipped in Kodak NTB-3 emulsion. The sections were lightly stained with haematoxylin and eosin to differentiate the theca and granulosa cell layers. For a semi-quantitative estimate of FSH binding, grain counts were made on stained sections. The number of grains over a random $0.025 \mathrm{~mm}^{2}$ area of granulosa cells in each of the four largest follicles ( $500 \mu \mathrm{m}$ in diameter) in each ovary was counted. Grain counts within the emulsion adjacent to ovarian sections were also made. Gonadotrophin binding was expressed as the difference between total grain counts over the granulosa cells and the grain counts within the emulsion. The ovaries were sectioned over a 5-day period with one ovary from each group sectioned on the same day.

Serum was prepared from each blood sample collected at autopsy and stored at $-20^{\circ} \mathrm{C}$ until assayed for FSH content. FSH was assayed by using the radioimmunoassay kit provided by NIAMDD. The sensitivity and intra-assay coefficient of variation of the assay was $8 \mathrm{ng} / \mathrm{ml}$ and $9 \%$ respectively. Values were expressed as ng NIH-FSH-RP1/ml serum.

\section{Experiment II}

Twenty-three (23) female rats, 24 days of age, were injected intraperitoneally with 5 i.u. PMSG. At 48, 56, 72 and $96 \mathrm{~h}$ after the injection, groups of 4 to 9 rats were given an i.p. injection of $\left[{ }^{3} \mathrm{H}\right]-$ thymidine $(50 \mu \mathrm{Ci}$; sp. act. $5 \mathrm{Ci} / \mathrm{mmol}$ : New England Nuclear). The rats were killed $3 \mathrm{~h}$ after the thymidine injection and the ovaries were removed, trimmed of fat, and weighed. One ovary from each rat was fixed in Bouin's solution; the other ovary was frozen and stored at $-20^{\circ} \mathrm{C}$ for $1-3$ days.

The Bouin-fixed ovary was embedded in paraffin wax, sectioned at $10 \mu \mathrm{m}$, dipped in Kodak NTB-3 emulsion and exposed at $4^{\circ} \mathrm{C}$ for 21 days. The labelling index was determined for all follicles greater than $500 \mu \mathrm{m}$ in diameter. The labelling index was determined by calculating the percentage of labelled nuclei within the largest diameter of the follicle. When ovarian sections, taken from rats which were not injected with $\left[{ }^{3} \mathrm{H}\right]$ thymidine, were prepared for autoradiography, 95 to $98 \%$ of the granulosa cells had 2 or less grains over their nuclei. Thus, a nucleus was considered labelled if it had 3 or more grains over its area. The probability that a label of more than 3 grains was due to background was $\leqslant 5 \%$.

To determine the total $\left[{ }^{3} \mathrm{H}\right]$ thymidine incorporated, the frozen ovary of each pair was homogenized in $4 \mathrm{ml} 2 \mathrm{~N}-\mathrm{HCl}$ and hydrolysed at $100^{\circ} \mathrm{C}$ for $1 \mathrm{~h}$. The solution was filtered (Whatman No. 1 paper) and $2 \mathrm{ml}$ filtrate were added to $10 \mathrm{ml}$ scintillant fluid (Scintiverse: Fisher Chemical Co.). The mixture was then counted for $5 \mathrm{~min}$ in a Tri-carb liquid scintillation counter. The results were expressed as c.p.m./mg ovary.

\section{Experiment III}

Rats, aged 24 days, were primed with 5 i.u. PMSG and $48 \mathrm{~h}$ later were sham hypophysectomized, hypophysectomized, or hypophysectomized and subcutaneously injected with $60 \mu \mathrm{g}$ ovine FSH (NIH-FSH-S17). Hypophysectomies were performed by the external auditory canal route (Koyama, 1962). All the rats were injected with $50 \mu \mathrm{Ci}\left[{ }^{3} \mathrm{H}\right]$ thymidine $24 \mathrm{~h}$ later and killed $3 \mathrm{~h}$ after the $\left[{ }^{3} \mathrm{H}\right]-$ thymidine injection. Incorporation of the $\left[{ }^{3} \mathrm{H}\right]$ thymidine and the labelling index were determined as described above. At autopsy, the sella turcica of each rat was examined under a dissecting microscope to check that the entire pituitary had been removed.

Statistical evaluations were made by Student's $t$ test.

\section{Results}

By $48 \mathrm{~h}$ after PMSG, preovulatory follicles measuring 500-600 $\mu \mathrm{m}$ in diameter had developed and their granulosa cells bound labelled FSH (Table 1). FSH binding then decreased at $56 \mathrm{~h}$, increased again at $72 \mathrm{~h}$, and then decreased again at $96 \mathrm{~h}$ after PMSG. The incorporation of $\left[{ }^{3} \mathrm{H}\right]$ thymidine did 
not alter, but the labelling index significantly decreased at $96 \mathrm{~h}$ (Table 2). Serum FSH concentrations remained unchanged (Table 1). In addition, pycnotic nuclei were observed within the follicles $96 \mathrm{~h}$ after PMSG, indicating that they were in Stage $I$ of atresia.

Table 1. The effect of PMSG on mean ( \pm s.e.m.) values for serum FSH concentration and FSH binding in immature rats

\begin{tabular}{|c|c|c|c|c|c|}
\hline & \multirow[b]{2}{*}{$\begin{array}{l}\text { Untreated } \\
\text { controls }\end{array}$} & \multicolumn{4}{|c|}{ Time after PMSG (h) } \\
\hline & & 48 & 56 & 72 & 96 \\
\hline No. of rats & 4 & 5 & 5 & 5 & 4 \\
\hline Serum FSH (ng/ml) & $194 \pm 25$ & $188 \pm 26$ & $230 \pm 39$ & $198 \pm 36$ & $160 \pm 29$ \\
\hline No. of follicles examined & $9^{*}$ & 12 & 14 & 19 & 16 \\
\hline FSH binding (grains $/ 0.1 \mathrm{~mm}^{2}$ ) & $782 \pm 118$ & $991 \pm 80$ & $661 \pm 27 \dagger$ & $957 \pm 117$ & $275 \pm 33$ \\
\hline
\end{tabular}

* Follicles less than $500 \mu \mathrm{m}$ in diameter.

$\dagger$ Significantly lower than at 48 or $72 \mathrm{~h}(P<0.05)$.

$\ddagger$ Significantly lower than at all other times $(P<0.05)$.

Table 2. The effect of PMSG on mean ( \pm s.e.m.) values for incorporation of $\left[{ }^{3} \mathrm{H}\right]$ thymidine and labelling index in immature rats

\begin{tabular}{lcccc}
\hline & \multicolumn{4}{c}{ Time after PMSG (h)* } \\
\cline { 2 - 5 } & 48 & 56 & 72 & 96 \\
\hline $\begin{array}{l}\text { No. of rats } \\
\begin{array}{l}\text { Incorporation of }\left[{ }^{3} \mathrm{H}\right] \text { thymidine } \\
\text { (c.p.m./mg) }\end{array}\end{array}$ & 4 & 5 & 5 & 9 \\
$\begin{array}{l}\text { No. of follicles examined } \\
\text { Labelling index (\%) }\end{array}$ & $201 \pm 26$ & $186 \pm 57$ & $181 \pm 31$ & $138 \pm 24$ \\
& 24 & 24 & 33 & 9 \\
\end{tabular}

* Rats were injected with $\left[{ }^{3} \mathrm{H}\right]$ thymidine at the times indicated and autopsied $3 \mathrm{~h}$ later.

$\dagger$ Significantly lower than at all other times $(P<0.05)$.

The results of Exp. III are shown in Table 3. The incorporation of $\left[{ }^{3} \mathrm{H}\right]$ thymidine and the labelling index were reduced only in the rats which were hypophysectomized. Some pycnotic nuclei were occasionally observed within the large follicles of the hypophysectomized rats. Values for the hypophysectomized rats treated with FSH were similar to those of the controls.

Table 3. The effect of hypophysectomy (hypox.) and FSH on mean ( \pm s.e.m.) incorporation of $\left[{ }^{3} \mathrm{H}\right]$ thymidine and labelling index in PMSG-primed rats

\begin{tabular}{lccc}
\hline & \multicolumn{3}{c}{ Treatment } \\
\cline { 2 - 4 } & Sham-hypox. & Hypox. + FSH & Hypox. \\
\hline $\begin{array}{l}\text { No. of rats } \\
\text { Incorporation of }\left[{ }^{3} \mathrm{H}\right] \text { thymidine } \\
\begin{array}{l}\text { (c.p.m./mg) } \\
\text { No. of follicles examined }\end{array}\end{array}$ & 10 & 6 & 4 \\
$\begin{array}{l}\text { Labelling index }(\%) \\
\text { abe }\end{array}$ & $167 \pm 19$ & $214 \pm 20$ & $95 \pm 11^{*}$ \\
\hline
\end{tabular}

The rats were killed $3 \mathrm{~h}$ after the injection of $\left[{ }^{3} \mathrm{H}\right]$ thymidine which was $24 \mathrm{~h}$ after operation and $72 \mathrm{~h}$ after PMSG treatment.

* Significantly different from value for sham-hypox. group (P<io.05)! 


\section{Discussion}

The present results show that FSH binding sites are maintained in large antral follicles for $72 \mathrm{~h}$, but are reduced by $96 \mathrm{~h}$ after PMSG treatment. This reduction in FSH binding is correlated with a decrease in the number of granulosa cell divisions (labelling index) and the appearance of pycnotic nuclei. When serum FSH is reduced by hypophysectomy, the granulosa cell divisions are reduced within $24 \mathrm{~h}$ and the follicles become atretic. Hypophysectomy of mature rats at pro-oestrus results in the preovulatory follicles losing their ability to ovulate within $12 \mathrm{~h}$ and they become atretic within $19 \mathrm{~h}$ (Talbert, Meyer \& McShan, 1951). Exogenous FSH, however, maintains the granulosa cell divisions and prevents the follicle from entering Stage I of atresia. It therefore appears that (1) FSH stimulates granulosa cell divisions in large antral follicles and (2) in intact rats, the reduction of FSH binding sites could account for the decrease in granulosa cell divisions and the subsequent atresia of the follicle.

Although FSH binding sites are maintained in the large follicles until $72 \mathrm{~h}$ after PMSG administration, the follicles have already developed acid phosphatase activity and lost their LH binding sites and ovulability (Peluso, Steger \& Hafez, 1977). In PMSG-primed rats, a sub-ovulatory LH surge occurs by $48 \mathrm{~h}$ (Peluso et al., 1977). Since LH, in the absence of FSH, triggers a simultaneous reduction in granulosa cell receptors for LH and FSH within $24 \mathrm{~h}$ (Richards et al., 1976), the LH surge observed in PMSG-primed rats could be responsible for the decrease in LH and FSH binding sites. However, FSH levels, which remain constant at approximately $200 \mathrm{ng} / \mathrm{ml}$, could maintain FSH binding sites (Richards et al., 1976), and thus account for the different rates at which LH and FSH binding sites are reduced.

This work was supported by Ford Foundation Grant 710-0287A and NIH Grant RR-05384.

\section{References}

Armstrong, D.T. \& Papkoff, H. (1976) Stimulation of aromatization of exogenous and endogenous androgens in ovaries of hypophysectomized rats in vivo by follicle-stimulating hormone. Endocrinology 99, $1144-1151$.

Byskov, A.G.S. (1974) Cell kinetic studies of follicular atresia in the mouse ovary. J. Reprod. Fert. 37, 277 285.

Dorrington, J.H., Moon, Y.S. \& Armstrong, D.T. (1975) Estradiol-17 $\beta$ biosynthesis in cultured granulosa cells from hypophysectomized immature rats; stimulation by follicle stimulating hormone. Endocrinology 97, 1328-1331.

GoldenberG, R.L., Vaitukaitis, J.L. \& Ross, G.T. (1972) Estrogen and follicle stimulating hormone interactions on follicle growth in rats. Endocrinology 90, 1492-1498.

GreENWALD, G.S. (1974) Role of follicle-stimulating hormone and luteinizing hormone in follicular development and ovulation. In Handbook of Physiology, Vol. III, pp. 293-323. Eds R. O. Greep \& E. B. Astwood. American Physiological Society, Washington, D.C.

Greenwood, F.C., Hunter, W.M. \& Glover, J.S. (1963) The preparation of ${ }^{131}$ I-labelled human growth hormone of high specific radioactivity. Biochem. J. 89, 114-120.

KoYAMA, R. (1962) A simple method of hypophysectomy in rats. (Koyama's External Auditory Canal Method). Endocr. Jap. 8, 321-323.
MidgleY, A.R. (1972) Autoradiographic analysis of gonadotrophin binding to rat ovarian tissue sections. In Receptors for Reproductive Hormones, pp. 365 378. Eds B. W. O'Malley \& A. R. Means. Plenum Press, New York.

Pederson, T. (1972) Follicle growth in the mouse ovary. In Oogenesis, pp. 361-376. Eds J. D. Biggers \& A. W. Schuetz. University Park Press, Baltimore.

Peluso, J.J., Steger, R.W. \& Hafez, E.S.E. (1976) Development of gonadotrophin-binding sites in the immature rat ovary. J. Reprod. Fert. 47, 55-58.

Peluso, J.J., Steger, R.W. \& Hafez, E.S.E. (1977) Sequential changes associated with the degeneration of preovulatory rat follicles. J. Reprod. Fert. 49, 215-218.

Richards, J.S., IREland, J.J., RaO, M.C., BERnath, G.A., Midgley, A.R. \& Reichert, L.E. (1976) Ovarian follicular development in the rat: hormone receptor regulation by estradiol, follicle-stimulating hormone and luteinizing hormone. Endocrinology 99, 1562-1570.

Talbert, G.B., Meyer, R.K. \& McShan, W.H. (1951) Effect of hypophysectomy at the beginning of proestrus on maturing follicles in the ovary of the rat. Endocrinology 49, 687-698.

WEIR, B.J. \& Rowlands, I.W. (1977) Ovulation and atresia. In The Ovary, 2nd edn, Vol. I, pp. 265-302. Eds S. Zuckerman \& B. J. Weir. Academic Press, New York.

Received 17 January 1978 